\title{
PENAFSIRAN SURAT AL-ANFAL AYAT KE-60 \\ MELALUI PENDEKATAN SEMIOTIKA \\ (Aplikasi Teori Semiotika Komunikasi Roman Jakobson)
}

\section{Oleh: Ahmad Riyadi ${ }^{1}$}

\begin{abstract}
Abstrak: Al-Qur'an merupakan salah satu media yang dijadikan Allah untuk berkomunikasi dengan hamba-Nya. Al-Qur'an memuat pesan-pesan yang di antaranya berupa perintah dan larangan baik secara langsung ataupun tidak langsung. Mengetahui pesan, dari siapa dan untuk siapa merupakan salah satu cara untuk memahami makna yang terkandung dalam pesan itu sendiri. Melalui pendekatan teori semiotika komunikasi, penulis mencoba menguraikan makna pesan yang terkandung dalam Al-Qur'an surat Al-Anfal, ayat ke-60. Kesimpulan dari artikel ini menyatakan bahwa dalam Al-Anfal ayat ke-60, Allah menyampaikan konsep bernegara, yaitu konsep menjaga kedaulatan dan keutuhan negara sehingga tercipta keamanan dan kenyamanan bagi semua warganya. Di samping itu juga Islam lebih menganjurkan pertahanan dari pada melakukan invansi dan itulah konsep perdamaian yang sempurna.
\end{abstract}

Kata Kunci: Surat Al-Anfal, Teori Semiotika, komunikasi, Roman Jakobson

\section{Pendahuluan}

Diktum "shalih li kulli zaman wa makan" (relevan dengan semua waktu dan tempat) merupakan salah satu keistimewaan Al-Qur'an. Akan tetapi diktum tersebut sekaligus menjadi tantangan bagi kaum muslimin untuk membuktikannya. Karena Al-Qur'an merupakan kitab suci terakhir yang diturunkan kepada manusia sebagai ajaran akumulatif dan penyempurna dari ajaran-ajaran kitab suci samawi sebelumnya. ${ }^{2}$ Para pemikir kontemporer menilai

1 Ahmad Riyadi, Mahasiswa Universitas Islam Negeri Sunan Kalijaga Yogyakarta Email: m4yd4773@gmail.com

2 Arif Budiono, "Penafsiran Al-Qur'an Melalui Pendekatan Semiotika Dan Antropologi (Telaah Pemikiran Muhammad Arkoun)," MIYAH: Jurnal Studi Islam 11, no. 2 (25 Februari 2017): 281 . 
bahwa pemahaman terhadap Al-Quran selalu bersifat terbuka. ${ }^{3}$ Dalam artian selalu berkembang sejalan dengan perkembangan zaman dan tidak boleh dimonopoli oleh sekelompok orang atau zaman tertentu. Oleh karena itu, jamal Al-Banna berpandangan bahwa tafsir-tafsir klasik merupakan produk masanya. ${ }^{4}$

Oleh karena itu dalam rangka merealisasikan keistimewaan Al-Qur'an di atas, harus ada usaha pemahaman terhadap Al-Qur'an dari masa ke masa. Namun jika metode pemahaman Al-Qur'an tetap mengikuti yang lama, maka tidak akan mampu menghasilkan pemahaman yang mampu menjawab setiap perubahan zaman. ${ }^{5}$ Sedangkan teks Al-Qur'an itu sendiri tetap yaitu teks yang diturunkan kepada bangsa yang soiso-kulturalnya sangat berbeda dengan negeri-negeri lain terlebih setelah berabad-abad lamanya. Oleh karena itu, para pemikir kontemporer berusaha menemukan motode-metode yang dinilai lebih dialektis, reformatif dan komunikatif. Salah satu metode yang ditawarkan adalah pemahaman Al-Qur'an menggunakan pendekatan semiotika.

Semiotika adalah ilmu tentang tanda-tanda, semiotika sendiri berasal dari bahasa Yunani, yaitu semeion yang berati tanda. ${ }^{6}$ Ruang lingkup kajian dari semiotika sangat luas tidak hanya terbatas pada tanda dalam percakapan seharihari. ${ }^{7}$ Namun diantara ruang lingkup kajian semiotika menurut Hjelemslev adalah meta bahasa. ${ }^{8}$ Adapun kaitan semiotika sebagai ilmu tanda dengan Al-Qur'an adalah Al-Qur'an merupakan kitab suci dengan kriteria sastra yang paling tinggi memuat lafaz “آية" pada ratusan ayat, sedangkan آية dalam Al-Qur'an memiliki arti dasar yaitu tanda.

Selain itu, Al-Qur'an sebagai kitab suci memuat pesan-pesan yang berisi perintah dan larangan. Dengan kata lain, Al-Qur'an merupakan salah satu media

3 Akhmad Muzakki, "Kontribusi Semiotika dalam Memahami Bahasa al-Quran," ISLAMICA: Jurnal Studi Keislaman 4, no. 1 (2 September 2009): 1, https://doi.org/10.15642/islamica.2009.4.1.35-48.

4 Mukhammad Zamzami, "Revolusi al-Qu'ran Jamâl al-Bannâ sebagai Arah Baru Metodologi Studi Islam," MUTAWATIR $5 \quad$ (10 September 2015): 24, https://doi.org/10.15642/mutawatir.2015.5.1.20-49.

5 Namun yang perlu ditekankan bahwa bagaimanpun, penafsiran modern tidak akan pernah lepas sama sekali dari metode-metode penafsiran ulama terdahulu.

6 Wildan Taufiq, Semiotika: untuk Kajian Sastra dan Al-Qur'an (Bandung: Yrama Widya, 2016), 1 .

${ }^{7}$ Ni Wayan Sartini, "Tinjauan Teoritik tentang Semiotik," t.t., 2.

${ }^{8}$ Wildan Taufiq, Semiotika: untuk Kajian Sastra dan Al-Qur'an, 4. 
yang dijadikan Allah untuk berkomunikasi dengan hamba-hamba-Nya. Pesanpesan yang ada dalam Al-Qur'an atau yang dikenal dengan istilah khithab assyar'i memiliki objek atau mukhothob yang berbeda-beda. Misalnya, perintah berbakti kepada orang tua, ditunjukkan kepada manusia dalam posisinya sebagai anak, begitu pula perintah untuk mendidik anak tertuju kepada manusia dalam posisinya sebagai orang tua dan begitu seterusnya. Inilah salah satu keistimewaan komunikasi Al-Qur'an, yang menyampaikan pesan dengan memperhatikan keadaan orang yang menerima pesan tersebut. Artinya mengetahui pesan dan kepada siapa pesan itu ditunjukkan akan membantu kita dalam memahami makna dari pesan itu sendiri.

Oleh karena itu, dalam artikel ini penulis mencoba menganalisa makna yang terkandung dalam surat Al-Anfal ayat ke-60 dengan menggunakan teori semiotika komunikasi Roman Jakobson atau yang lebih dikenal dengan teori code-message. Penulis menjadikan surat Al-Anfal ayat ke-60 sebagai objek analisa, karena ayat tersebut berkaitan dengan konsep Al-Qur'an dalam menjaga kedaulatan sebuah bangsa. Penulis menilai bahwa pembahasan ini jarang dibahas, dalam artian sedikit sekali yang mencoba mengambil pelajaran dari Al-Qur'an tentang bagaimana Islam mengatur kedaulatan sebuah bangsa. Karena salah satu sisi kesempurnaan syari'at Islam adalah mengatur seluruh aspek kehidupan manusia. Mulai dari kehidupan berkeluarga, bermasayarakat bahkan berbangsa dan bernegara.

\section{Pembahasan}

\section{Teori Code-Message Roman Jakobson}

\section{Sekilas Biografi Roman Jakobson}

Roman Jakobson lahir pada tahun 1896 di Moskow. Ia merupakan ahli linguistik abad ke dua puluh yang sangat menonjol dengan mengembangkan pendekatan strukturalis dalam kajian bahasa. Yang demikian itu, dikarenakan ia merupakan murid dari Nikolai Trubetskoy, salah seorang ahli fonologi Rusia pengikut strukturalisme Saussure. ${ }^{9}$ Pada tahun 1914, Jakobson memasuki fakultas historiko-filologis di Universitas Moskow dan masuk bagian bahasa di jurusan Slavia dan Rusia. Telaah bahasa menjadi kunci dalam upaya memahami sastra dan folklore (cerita

\footnotetext{
${ }^{9}$ Wildan Taufiq, 41.
} 
rakyat). Pada tahun 1915, Jakobson mendirikan lingkungan linguistik di Moskow dan terpengaruh oleh pemikiran Husserl. Sehingga Husserl merupakan tokoh yang cukup penting dalam membentuk pemikirannya. ${ }^{10}$

Menjelang akhir tahun 1920, Jakobson meninggalkan Moskow dan tinggal di Praha. Ia menjadi anggota linguistik Praha yang paling berpengaruh sejak didirikannya organisasi tersebut pada tahun 1926. Di kota inilah ia tertarik untuk mempelajari perbedaan antara struktur fonik dan prosodik dalam bahasa Rusia dan bahasa Slavik lainnya. ${ }^{11}$

Pada tahun 1930-an, Jakobson bersama dengan Nikolai Trubetskoy melakukan penelitian tentang pola suara pada bahasa. Sebagai pengikut Saussure, Trubetskoy mengarahkan Jakobson pada gagasan bahwa suara dalam bahasa berfungsi secara diferensial. Suara tidak memiliki makna intrinsik. ${ }^{12}$

Pada tahun 1930-an akhir, bersamaan dengan bangkitnya Nazisme serta semakin dekatnya peperangan, Jakobson berkelana ke Swedia dan Denmark. Di Copenhagen, ia bergabung dengan lingkar studi linguistik bersama Hjlemslev. Di sana Jakobson menerbitkan karyanya yang berjudul Kindersparache, Aphasie undnAllgemeine Lautgesetze. Karya tersebut ditulisnya sebelum berangkat ke Amerika. Pada tahun 1950, Jakobson berangkat ke Amerika. Di sana ia diangkat sebagai dosen di Universitas Harvard dan Institut Teknologi Masachussetts. Jakobson tinggal di Amerika hingga ajal menjemputnya pada tahun 1982. ${ }^{13}$

\section{Teori Code-Message}

Menurut Jakobson, subjek kajian semiotika adalah komunikasi pada pesan apa saja. Berbeda dengan linguistik yang hanya mengkaji komunikasi pada pesan verbal. Semiotika mengkaji komunikasi, baik pada pesan verbal maupun nonverbal. Menurutnya, pesan komunikasi non-verbal apap pun dianggap sebagai pesan verbal. Secara tersirat, Jakobson menegaskan bahwa semiotika adalah ilmu

\footnotetext{
${ }^{10}$ Alex Sobur, Semiotika Komunikasi (Bandung: PT. Remaja Rosdakarya, 2006), 57.

${ }^{11}$ Wildan Taufiq, Semiotika: untuk Kajian Sastra dan Al-Qur'an, 42.

${ }^{12}$ Wildan Taufiq, 42.

${ }^{13}$ Wildan Taufiq, 42.
} 
yang mengkaji tentang pesan-pesan yang terdapat dalam komunikasi antar tanda, baik berupa tanda verbal maupun non-verbal. ${ }^{14}$

Menurut Jakobson, bahasa memiliki enam masam fungsi ${ }^{15}$, yaitu:

1. fungsi referansial, pengacu pesan

2. fungsi emotif, pengungkap keadaan pembicara

3. fungsi konatif, pengungkap keinginan pembicara yang langsung atau segera dilakukan atau dipikirkan oleh penerima pesan

4. fungsi metalingual, penerang sandi atau kode yang digunakan

5. fungsi fatis, pembuka, pembentuk, pemelihara hubungan atau kontak antara pembicara dengan penyimak

6. fungsi puitis, penyandi pesan.

Dalam artikelnya yang terkenal Linguistics and Poetics, Jakobson menerangkan adanya fungsi bahasa yang berbeda yang merupakan faktor-faktor pembentuk dalam setiap jenis komunikasi verbal. Addresser (pengirim) mengirimkan sesuaru mesaage (pesan) kepada seorang addresse (penerima). Agar komunikasi beroprasi, pesan tersebut memerlukan context (konteks), sehingga dipahami oleh yang dikirimi dan dapat diverbalisasikan dalam sebuah code (kode) secara penuh atau paling tidak sebagian dikenal oleh addresser ataupu addresse. Akhirnya suatu contact (kontak), suatu saluran fisik dan hubungan psikologis antara pengirim dan penerima memungkinkan keduanya memasuki dan berada dalam komunikasi. ${ }^{16}$

Oleh karena itu, setiap kemunikasi verbal atau yang diverbalkan tersusun dari enam unsur yaitu: pertama, Addresser (pengirim), kedua, Addresse (penerima pesan), ketiga, Message (pesan), keempat, code (makna dari pesan), kelima, context (konteks) ,keenam, contact (kontak). Proses komunikasi verbal dapat disekemakan sebagai berikut:

\footnotetext{
${ }^{14}$ Wildan Taufiq, 43.

${ }^{15}$ Sobur, Semiotika Komunikasi, 56.

${ }^{16}$ Sobur, 58.
} 
CONTEXT

MESSAGE

ADDRESSER

-ADDRESSEE

CONTACT

CODE

Dua hal yang menjadi point penekanan dalam teori Jakobson adalah kode dan konteks. Kode merupakan makna di balik suatu pesan hal ini bisa difahami dari konteks pesan yang disampaikan oleh Pengirim kepada penerima.

\section{Al-Anfal 60}

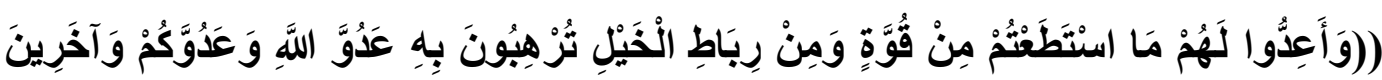

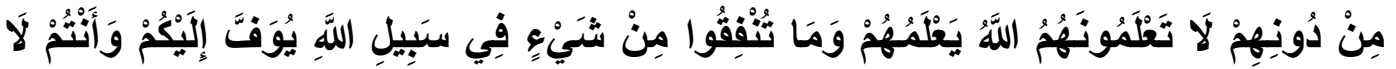
نُظْلَلْوَونَ)

"Dan siapkanlah untuk menghadapi mereka kekuatan apa saja yang kamu sanggupi dan dari kuda-kuda yang ditambat untuk berperang (yang dengan persiapan itu) kamu menggetarkan musuh Allah, musuhmu dan orang-orang selain mereka yang kamu tidak mengetahuinya; sedang Allah mengetahuinya. Apa saja yang kamu nafkahkan pada jalan Allah niscaya akan dibalas dengan cukup kepadamu dan kamu tidak akan dianiaya (dirugikan).”

\section{Sekilas tentang Perang Badar}

perang besar yang pertama kali terjadi antara orang-orang kafir dengan orang-orang mukmin. Pasukan kaum muslimin pada perang badar hanya berjumlah tiga ratusan lebih ${ }^{17}$ dengan 70 ekor unta dan dua ekor kuda. ${ }^{18}$ Jumlah pasukan yang kecil dengan perlengkapan perang yang minim ini disebabkan karena tujuan awal dari keluarnya kaum muslimin dari kota madinah adalah untuk

${ }^{17}$ Penulis tidak menyebutkan jumlah yang pasti karena memang para muarrikh berselisih pendapat tentang jumlah pasukan kaum muslimn pada perang badr.

${ }^{18}$ Shofiyurrahman Al-Mubarokfuri, Ar-Rohiq Al-Makhtum (Bairut: Dar Al-Hilal, t.t.), 1/ 184. 
mencegat kafilah dagang suku quraisy yang baru pulang dari negeri Syam. Sedangkan kafilah dagang tersebut hanya dikawal oleh 30 atau 40 orang saja yang diketuai oleh Abu Sufyan. Oleh karena itu, nabi tidak menyiapkan pasukan yang besar bahkan beliau merahasiakan rencana tersebut.

Di sisi lain, pasukan suku Quraisy yang berhadapan dengan kaum muslimin berjumlah sangat besar. Hal ini disebabkan oleh tujuan mereka yang memang keluar dari kota mekkah untuk berperang. Jumlah pasukan suku Quraisy pada perang badar yaitu seribu pasukan yang terdiri dari 200 penunggang kuda, 600 pasukan bertameng, dan unta dengan jumlah yang tak terhitung. Dalam hal ini, kaum muslimin berhadapan dengan pasukan musuh yang berjumlah tiga kali lipat dari jumlah mereka dengan perlengkapan perang dan persenjataan yang lengkap.

\section{Wa A'iddu (Siapkanlah)}

Lafaz 'أعدو' merupakan bentuk amr (kata perintah) dari kata أعد- يعد yang artinya menyiapkan. Maka lafaz أعدوا memiliki arti perintah untuk melakukan persiapan atau perintah untuk selalu siap siaga. ${ }^{19}$ Dalam kaidah Ushul dikatakan: الأمر يقتضي الوجوب (setiap kata perintah mengandung makna wajib), maka perintah untuk menyiapkan segala bentuk kekuatan dalam rangka berperang merupakan suatu kewajiban.

Perintah pada ayat ini diperuntukkan kepada kaum muslimin karena pada kata وأعدوا terdapat wawu jama'ah yang menunjukkan bahwa subjeknya jamak, maka perintah tersebut berlaku untuk semua kaum muslimin.

\section{Al-Quwwah (Kekuatan)}

Kata Quwwah (kekuatan) pada ayat ini dalam bentuk nakirah, sedangkan kaidah Ushul menyatakan: النكرة في سياق الإثبات تفيد العموم (nakirah pada konteks penetapan bermakna umum $)^{20}$. Maka kata quwwah bersifat umum, mencakup segala bentuk kekuatan yang bisa membantu pasukan dalam menghadapi musuh.

\footnotetext{
${ }^{19}$ Penulis memaknainya sebagai perintah untuk selalu siaga menghadapi musuh, karena ayat ini turun setelah perang Badr, sedangkan Allah tidak mengabarkan akan terjadi perang dikemudian hari setelah perang Badr tersebut.

${ }^{20}$ Abdurrahman Bin Nashir As-Sa'di, Al-Qowa'id Al-Hisan Li Tafsir Al-Qur'an, 1 ed. (Riyadh: Maktab Ar-Rusyd, 1999), 1/ 16.
} 
Imam Muslim, Abu Daud dan yang lainnya meriwayatkan hadits dari sahabat Uqbah bin Amir bahwasanya nabi pernah berkhutbah di atas mimbar dengan membacakan surat Al-Anfal: 60, kemudian beliau bersabda: “ أَلَ إِنَّ الْقُوَّةَ

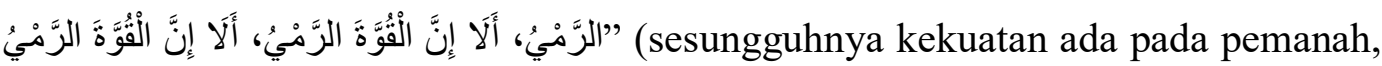
sesunggguhnya kekuatan ada pada pemanah, sesungguhnya kekuatan ada pada pemanah). ${ }^{21}$ At-Thobari mengomentari hadits tersebut dengan mengatakan:

"Hadits tersebut tidak menunjukkan bahwa yang dimaksud (dengan quwwah) adalah panah secara khusus tanpa melihat pada makna yang lain. Panah merupakan salah satu diantara cakupan makna kekuatan. Dan juga, di dalam hadits disebutkan "sesungguhnya kekuatan adalah panah" tanpa menyebutkan "bukan yang lainnya". Dan termasuk kekuatan juga adalah pedang, tombak, harbah dan setiap perbekalan guna melawan orang-orang musyrik."

Pendapat ini disepakati oleh Ar-Rozi dengan mengatakan:

"Sabda Nabi yang mengatakan "Sesungguhnya kekuatan adalah panah" bukan berarti yang lainnya tidak dianggap, sebagaimana sabda beliau "Haji adalah (wukuf di) Arafah" dan "Penyesalan adalah taubat" bukan menafikan yang lainnya. Akan tetapi menunjukkan bahwa sesuatu yang disebut memiliki keistimewaan, sebagaimana pada hadits ini."

Oleh karena itu, Al-Baidhowi menambahkan:

"Nabi menyebutnya secara khusus karena termasuk kekuatan yang paling berpengaruh"

Pasukan pemanah ini terbukti sangat ampuh dalam melindungi kekuatan musuh ketika perang Uhud. Pasukan pemanah yang berjumlah hanya lima puluh orang saja, mampu melindungi pasukan dari serangan musuh yang jumlahnya jauh lebih besar. Oleh karena itu, dalam banyak riwayat, Nabi sangat menganjurkan para sahabatnya untuk berlatih memanah. Sisi lain dari pasukan pemanah adalah mereka mampu melumpuhkan musuh dari jarak jauh sehingga bisa meminimalisir adanya kontak langsung dengan pasukan musuh. Dalam artian

${ }^{21}$ Sulaiman Bin Asy’asy As-Sajistani Abu Daud, Sunan Abi Daud (Bairut: Maktabah AlAshriyah, t.t.), 3/ 13/2514; An-Naisaburi Muslim Bin Hajjah, Shahih Muslim (Bairut: Dar Ihya' At-Turots Al-Arobi, t.t.), 3/ 1522/ 1917. 
ketika mereka mampu menaklukkan musuh dari jarak jauh, maka itulah kemenangan.

\section{Ribath Al-Khoil}

Kata Ribath berasal dari kata ربط - يربط yang berarti mengikat, sedangkan ribath berarti berari ما ربط بـ (sesuatu yang diikat dengannya), bentuk jamaknya ملازمة ثغر العدو Kata ribath juga berarti Al-Murobathoh yang bermakna. الربط. (berjaga di wilayah perbatasan). ${ }^{22}$ Kata Al-Khoil bermakna jamak, artinya sekumpulan kuda. ${ }^{23}$ Maka makna dari lafaz ribath Al-Khoil adalah kuda yang dipersiapkan untuk menghadapi musuh di daerah perbatasan.

Kata khoil bisa berarti kuda betina dan juga kuda pejantan. Ar-Rozi mengatakan bahwa mengartikan kata khoil dengan kuda jantan lebih tepat,karena tujuan dari menyiapkan kuda adalah untuk peperangan sedangkan kuda jantan lebih kuat dari kuda betina. ${ }^{24}$

Lafaz ribath Al-Khoil yang diathfkan (diikutkan) kepada lafaz quwwah merupakan bentuk 'Athf Al-Khosh 'Ala Al-Am (mengikutkan kata yang khusus kepada kata yang umum) yang menujukkan makna keistimewaan pada lafaz yang khusus. As-Suyuthi mengatakan:

(وفائدنه التنبيه على فضله حتى كأنه ليس من جنس العام تنزيلا للتغاير في الوصف منزلة التغاير في الذات) "tujuannya adalah memberi penekanan akan keistimewaan (lafaz yang khusus tersebut) seakan-akan kata tersebut tidak termasuk bagian dari lafaz yang umum, karena perbedaan sifat sama dengan perbedaan dzat." ${ }^{25}$ Dalam artian bahwa penyebutan kuda secara terpisah dari makna lafaz Quwwah mengindikasikan bahwa kuda memiliki keistimewaan tersendiri. Al-Qur'an sendiri menyebutkan kuda dalam banyak ayat, seperti dalam surat Al-'Adiyat yang mana Allah bersumpah dengan kuda perang yang berlari kencang. Kuda memang erat hubungannya dengan peperangan, karena salah satu harta yang menjadi ghanimah

\footnotetext{
${ }^{22}$ Muhammad bin Mukrom Ibn Al-Manzhur, Lisan Al-Arob (Bairut: Dar Shodir, 1414), $7 / 302$.

${ }^{23}$ Ibn Al-Manzhur, 11/ 231.

${ }^{24}$ Abu Abdillah Muhammad Bin Umar Ar-Rozi, Mafatih Al-Ghaib (Bairut: Dar Ihya' AtTurats Al-Arobi, 1420).

25 Abdurrahman Bin Abi Bakr As-Suyuthi, Al-Itqon Fi Ulum Al-Qur'an (Mesir: AlHai'ah Al-Mishriyah Al-’Ammah Lil Kitab, 1974), 3/ 240.
} 
(rampasan perang) adalah kuda (Al-Hasyr: 6). Selain itu, kuda juga disebutkan di dalam Al-Qur'an sebagai perhiasan dan kendaraan (Ali Imran: 14, An-Nahl:8, Shad: 31-32).

\section{Musuh Lain}

Dalam ayat ini, tujuan dari perintah menyiapkan kekuatan militer adalah untuk menghadapi musuh. Sedangkan musuh yang di maksudkan ada dua, yaitu: pertama, عدو الله و عدوكم (musuh Allah dan musuh kaum muslimin) dan yang kedua, musuh yang tidak diketahui. Yang dimaksud dengan musuh pertama adalah kuffar Makkah, berdasarkan konteks ayat. Adapun musuh kedua, yaitu musuh lain yang tidak diketahui, maka para ulama tafsir berselisih pendapat.

Ibnu Jarir Ath-Thobari berpendapat bahwa yang dimaksud dengan musuh lain adalah bangsa Jin. Ia berasalan bahwa orang-orang Yahudi, Persia, orangorang munafik dan yang lainnya telah diketahui permusuhan mereka oleh kaum muslimin. Sedangkan Jin, kaum muslimin tidak mengetahui keberadaan mereka dikarenakan mereka tidak terlihat. Di samping itu, satu riwayat mengatakan:

$$
\text { "إن صهيل الخيل ير هب الجن، وأن الجن لا تقرب دارًا فيها فرس" }
$$

"Sesungguhnya suara kuda ditakuti oleh Jin, dan mereka tidak akan mendekati rumah yang ada padanya Kuda."

Menurut At-Thobari,riwayat di atas sejalan dengan perintah Allah untuk menyiapkan kuda sebagai kekuatan untuk menghadapi musuh dari bangsa Jin. ${ }^{26}$

At-Thobari menolak pendapat yang mengatakan bahwa musuh lain yang dimaksud adalah orang-orang munafiq, karena orang-orang munafik tidak merasa takut dengan pasukan berkudanya kaum muslimin bahkan dengan persenjataan mereka. Akan tetapi orang-orang munafik hanya takut jika rahasia kemunafikan mereka terbongkar. sedangkan Allah memerintahkan kaum muslimin untuk menyiapkan kekuatan perang agar musuh-musuh merasa takut. Adapun musuh yang tidak takut dengan kekuatan tersebut, bukanlah musuh yang dimaksudkan oleh Allah dalam ayat ini. ${ }^{27}$

\footnotetext{
2000), 14/ 38 .

${ }^{27}$ Abu Ja'far Ath-Thabari, 14/ 38.
}

${ }^{26}$ Abu Ja'far Ath-Thabari, Jami' Al-Bayan Fi Ta'wil Al-Qur'an (Muassash Ar-Risalah, 
Lain halnya dengan Ibnu Katsir yang menguatkan pendapat yang mengatakan bahwa yang dimaksud musuh lain yang tidak diketahui oleh kaum muslimin adalah orang-orang munafik. ${ }^{28}$ Ibnu Katsir berdalil dengan At-Taubah ayat yang ke-101:

$$
\text { (وممن حولكم من الأعراب منافقون ومن أهل المدينة مردوا على النفاق لا تعلمهم نحن نعلمه) ) }
$$

"Di antara orang-orang Arab Badwi yang di sekelilingmu itu, ada orang-orang munafik; dan (juga) di antara penduduk Madinah. Mereka keterlaluan dalam kemunafikannya. Kamu (Muhammad) tidak mengetahui mereka, (tetapi) Kami-lah yang mengetahui mereka."

Namun, pendapat yang lebih kuat menurut pandangan penulis adalah pendapat yang mengatakan bahwa yang dimaksud dengan musuh lain yang tidak diketahui oleh kaum Muslimin adalah setiap orang atau kelompok yang tidak diketahui permusuhannya terhadap kaum muslim. Pendapat ini adalah pendapat As-Suhaili yang dikuatkan oleh As-Syaukani dalam kitab tafsirnya. ${ }^{29}$ Dalam hal ini adalah selain orang-orang musyrik Makkah dan sekutunya ${ }^{30}$, karena tidaklah kaum muslimin berhijrah ke kota Madinah kecuali adanya permusuhan dan penindasan dari orang-orang musyrik Mekkah. Adapun jika makna musuh lain diartikan dengan jin, maka dalam sejarah peperangan kaum muslimin, kaum muslimin tidak pernah melakukan peperangan dengan bangsa jin. Dan hadits yang dijadikan sandaran oleh At-Thobari dinilai lemah atau bahkan munkar oleh Ibnu Katsir. ${ }^{31}$ Begitu juga dengan orang-orang munafik sebagaimana yang dikatakan oleh At-Thobari, karena pada kenyataannya mereka berada di barisan kaum muslimin. Maka tidak ada yang perlu ditakutkan dari kekuatan kaum muslimin.

\footnotetext{
${ }^{28}$ Abu Al-Fida' Ibnu Katsir, Tafsir Al-Qur'an Al-'Azhim (Dar Thaybah, 1999), 4/ 83.

29 Muhammad Bin Ali Asy-Syaukani, Fath Al-Qodir (Bairut: Dar Kalm Ath-Thoyib, 1414), $2 / 366$.

30 Yang dimaksudkan dengan sekutu orang-orang musyrik Makkah adalah Bani Quraizhoh, mereka mengkhianati piagam madinah dengan membantu orang-orang musyrik Makkah dengan persenjataan pada perang Badr, lihat: Muhammad Umar Nawawi Al-Jawi AlBantani, Maroh Labid Li Kasfy Ma'ani Al-Qur'an Al-Majid, 1 ed. (Bairut: Dar Al-Kutub Al'Ilmiyah, 1417), 1/ 430.

${ }^{31}$ Abu Al-Fida' Ibnu Katsir, Tafsir Al-Qur'an Al-'Azhim, 4/ 82.
} 


\section{Aplikasi Code-Message Roman Jakobson}

Uraian di atas jika dianalisa dengan teori code-message Roman Jakobson, maka yang bertindak sebagai addresser pada ayat di atas adalah Allah, kemudian addresse atau dalam istilah balaghah disebut dengan mukhotob adalah kaum muslimin. Adapun pesan yang terkandung dalam ayat di atas adalah perintah untuk membentuk kekuatan militer guna menjaga kedaulatan wilayah kaum muslimin. Sedangkan konteks yang mendasari perintah ini adalah keadaan kaum muslimin yang masih lemah dari sisi kekuatan militer, baik dari jumlah pasukan ataupun pesenjataan perang yang mana kaum muslimin baru memiliki wilayah kedaulatan. Adapun kode yang merupakan makna yang terkandung dalam pesan ayat di atas adalah

1. Kaum muslimin harus selalu dalam keadaan siap menghadapi musuh, baik yang tampak ataupun tersembunyi dengan persiapan baik secara materi maupun maknawi.

2. Kaum muslimin tidak boleh memulai peperangan sekalipun terhadap musuh yang nyata, karena Allah tidak memerintahkan mereka kecuali untuk siaga.

3. Perintah untuk menempatkan kekuatan militer yang memiliki mobilisasi tercepat di daerah yang berbatasan langsung dengan daerah musuh, karena daerah perbatasan merupakan pintu masuknya musuh. Sehingga ketika ada musuh yang mencoba menyerang, maka informasi tersebut dengan cepat sampai ke pusat militer. Sehingga keadaan darurat dengan cepat tertangani.

3. Bahwasanya tujuan dari menyiapkan kekuatan militer dalam Islam adalah agar jangan sampai terbersit di benak musuh-musuh Islam untuk berbuat makar terhadap kaum muslimin. Sehingga kaum muslimin dan orang-orang yang berada di bawah perlindungan mereka mendapatkan rasa aman. ${ }^{32}$

4. Kaum Muslimin harus bersedia mengerahkan segala kemampuan mereka dalam mempertahankan kedaulatan wilayah mereka.

Adapun kontak yang terjadi antara addresser dengan addresse adalah perintah sang khaliq yaitu Allah kepada para hamba-hambanya. Sehingga dalam hal ini kewajiban seorang hamba untuk selalu berusaha merealisasikan perintah tersebut, tentu dalam kadar kemampuan mereka.

Kontekstualisasi Pesan Surat Al-Anfal Ayat: 60

${ }^{32}$ Muhammad Sayyid Thanthawi, At-Tafsir Al-Washit Li Al-Qur'an Al-Karim, 1 ed. (Kairo: Dar An-Nahdhah, 1997), 6/ 143. 
Dalam ayat ke-60 dari surat Al-Anfal ini terkandung konsep-konsep ketahanan nasional guna mempertahankan kedaulatan sebuah Negara. Konsepkonsep tersebut sebagai berikut:

1. Setiap negara harus memiliki kekuatan militer dalam rangka menjaga kedaulatannya dari pihak-pihak yang ingin merampas kedaulatan tersebut. Dalam menyusun kekuatan militer, tentunya harus mengikuti perkembangan zaman, karena di dalam ayat tersebut Allah befirman: ما استطعتم (apa saja yang kalian mampu persiapkan). Tentunya kemampuan militer pada setiap zaman berbeda dan terus berkembang. Nabi menyebutkan panah sebagai salah satu bentuk kekuatan menembak pada zaman itu karena kemampuannya melumpuhkan musuh dari jarah jauh. Maka senjata tersebut sudah berkembang dengan adanya senjatasenjata yang bisa membidik musuh dari jarak jauh.

2. Memberlakukan wajib militer bagi setiap warga negara karena perintah tersebut bersifat umum. Bagaimana jika negara telah memiliki pasukan khusus?. maka jawabannya adalah perintah tersebut masih berlaku, karena hukum melakukan pertempuran berbeda dengan hukum melakukan persiapan perang. Ibnu Hajar dalam kitabnya fath al-bari menjelaskan hukum yang berkaitan dengan kewajiban untuk ikut serta dalam peperangan. Ia membaginya menjadi dua periode yaitu periode Nabi masih hidup dan periode setelah Nabi wafat. Para ulama berbeda pendapat tentang hukum ikut serta dalam peperangan pada masa Nabi masih hidup. Akan tetapi mereka sepakat bahwa setelah Nabi wafat maka kewajiban ikut serta dalam peperangan bersifat fardhu kifayah, dalam artian jika telah ada sekelompok orang yang mumpuni melaksanakannya, maka gugur kewajiban bagi yang lain. Namun jika situasi dan kondisi mengharuskan, maka wajib bagi setiap orang untuk ikut serta dalam pertempuran. ${ }^{33}$

\section{Kesimpulan}

Dari uraian diatas, penulis menyimpulkan bahwa Islam tidak hanya mengatur hubungan seorang hamba dengan penciptanya dalam bentuk ibadah. Akan tetapi lebih dari itu, melalui Al-Qur'an yang menjadi pedoman hidup bagi

\footnotetext{
${ }^{33}$ Ahmad Bin Ali Ibnu Hajar Al-Asqolani, Fath Al-Bari Syarh Shahih Al-Bukhari (Bairut: Dar AlMa'rifah, 1379), 6/ 37.
} 
kaum muslimin Islam telah menjelaskan sebuah konsep bernegara yang begitu apik guna menciptakan situasi yang aman. Islam tidak memerintahkan untuk melakukan peperangan, namun jika diserang maka kaum muslimin haruslah siap.

\section{Daftar Pustaka}

Abu Al-Fida' Ibnu Katsir. Tafsir Al-Qur'an Al-'Azhim. Dar Thaybah, 1999.

Abu Daud, Sulaiman Bin Asy'asy As-Sajistani. Sunan Abi Daud. Bairut: Maktabah Al-Ashriyah, t.t.

Abu Ja'far Ath-Thabari. Jami' Al-Bayan Fi Ta'wil Al-Qur'an. Muassash ArRisalah, 2000.

Al-Jawi Al-Bantani, Muhammad Umar Nawawi. Maroh Labid Li Kasfy Ma'ani Al-Qur'an Al-Majid. 1 ed. Bairut: Dar Al-Kutub Al-'Ilmiyah, 1417.

Al-Mubarokfuri, Shofiyurrahman. Ar-Rohiq Al-Makhtum. Bairut: Dar Al-Hilal, t.t.

Ar-Rozi, Abu Abdillah Muhammad Bin Umar. Mafatih Al-Ghaib. Bairut: Dar Ihya' At-Turats Al-Arobi, 1420.

As-Sa'di, Abdurrahman Bin Nashir. Al-Qowa'id Al-Hisan Li Tafsir Al-Qur'an. 1 ed. Riyadh: Maktab Ar-Rusyd, 1999.

As-Suyuthi, Abdurrahman Bin Abi Bakr. Al-Itqon Fi Ulum Al-Qur'an. Mesir: AlHai'ah Al-Mishriyah Al-'Ammah Lil Kitab, 1974.

Asy-Syaukani, Muhammad Bin Ali. Fath Al-Qodir. Bairut: Dar Kalm AthThoyib, 1414.

Budiono, Arif. "Penafsiran Al-Qur'an Melalui Pendekatan Semiotika Dan Antropologi (Telaah Pemikiran Muhammad Arkoun)." MIYAH: Jurnal Studi Islam 11, no. 2 (25 Februari 2017): 281-306.

Ibn Al-Manzhur, Muhammad bin Mukrom. Lisan Al-Arob. Bairut: Dar Shodir, 1414.

Ibnu Hajar Al-Asqolani, Ahmad Bin Ali. Fath Al-Bari Syarh Shahih Al-Bukhari. Bairut: Dar Al-Ma'rifah, 1379.

Muslim Bin Hajjah, An-Naisaburi. Shahih Muslim. Bairut: Dar Ihya' At-Turots Al-Arobi, t.t.

Muzakki, Akhmad. "Kontribusi Semiotika dalam Memahami Bahasa al-Quran." ISLAMICA: Jurnal Studi Keislaman 4, no. 1 (2 September 2009): 35-48. https://doi.org/10.15642/islamica.2009.4.1.35-48.

Sartini, Ni Wayan. “Tinjauan Teoritik tentang Semiotik,” t.t., 8.

Sobur, Alex. Semiotika Komunikasi. Bandung: PT. Remaja Rosdakarya, 2006. 
Thanthawi, Muhammad Sayyid. At-Tafsir Al-Washit Li Al-Qur'an Al-Karim. 1 ed. Kairo: Dar An-Nahdhah, 1997.

Wildan Taufiq. Semiotika: untuk Kajian Sastra dan Al-Qur'an. Bandung: Yrama Widya, 2016.

Zamzami, Mukhammad. "Revolusi al-Qu'ran Jamâl al-Bannâ sebagai Arah Baru Metodologi Studi Islam." MUTAWATIR 5 (10 September 2015): 20. https://doi.org/10.15642/mutawatir.2015.5.1.20-49. 